\title{
Choice modeling: assessing the non-market environmental values of the biodiversity conservation of swamp forest in Vietnam
}

\author{
Huynh Viet Khai · Mitsuyasu Yabe
}

Received: 28 December 2013/ Accepted: 22 February 2014/Published online: 5 March 2014

(c) The Author(s) 2014. This article is published with open access at Springerlink.com

\begin{abstract}
The study investigated the economic value of biodiversity attributes that could provide policy makers reliable information to estimate welfare losses due to biodiversity reductions and analyze the trade-off between biodiversity and economics. To obtain the non-market benefits of biodiversity conservation, an indirect utility function and willingness to pay for biodiversity attributes were applied using the approach of choice modeling with the analysis of multinomial logit model. The study found that Mekong Delta residents accepted their willingness to pay of VND 913 monthly for a $1 \%$ increase in healthy vegetation, VND 360 for an additional mammal species and VND 2,440 to avoid the welfare losses of 100 local farmers.
\end{abstract}

Keywords Choice modeling - Genetic resources · Wetland conservation - Marginal willingness to pay

\section{Introduction}

The wetlands in the Mekong Delta, the largest wetlands in Vietnam, have great biodiversity. They support a large number of herons, egrets, stocks, ibises and some rare

H. V. Khai $(\bowtie)$

Agricultural, Resource and Environmental Economics, School of Economics and Business Administration, Can Tho University,

Can Tho, Vietnam

e-mail: hvkhai@ctu.edu.vn

M. Yabe

Laboratory of Environmental Economics, Department of Agricultural and Resource Economics, Faculty of Agriculture, Kyushu University, Hakozaki 6-10-1, Higashi-ku,

Fukuoka 812-8581, Japan

e-mail: yabe@agr.kyushu-u.ac.jp species such as sarus cranes, black-necked storks, lesser adjutants and great adjutants. Especially, there are 14 globally threatened bird species among 194 bird species living in the mature semi-natural Melaleuca forest and seasonally inundated grasslands of the Mekong Delta. Conservation of Mekong Delta wetlands is beneficial not only for Vietnam, but also for the world. For instance, in the wetlands there are a lot of unknown flora and fauna, microorganisms and genetic resources that are expected to contribute to the future development of new medicines or coenzymes necessary for biochemical reaction.

However, the Mekong Delta has faced problems of much environmental pollution and an increase in wetland destruction due to the rapid development of industries. Recently, the wetlands in the Mekong Delta have experienced serious biodiversity losses and degradation. For instance, the numbers of endangered species in Tram Chim National Park, one of the largest national wetland parks, have rapidly reduced from 1,057 in 1987 to 93 in 2005 [12]. In addition, the losses of wetland biodiversity also is due to an increase in shrimp farming, the conversion of wetlands to agriculture and construction land, war destruction and excessive fuel wood collection [12]. To prevent the biodiversity losses and degradation, the local authorities have proposed plans to use public funding to improve the protection of biodiversity. However, up to now there is little information on the values of biodiversity as well as studies on nature and biodiversity conservation in Vietnam's literature. Thuy [24] conducted a study on the willingness to pay for the conservation of Vietnamese rhinoceros using contingent valuation method with five bid-level questionnaires and estimated the mean WTP of $\$ 2.5$ per household. Environmental choice modeling was applied by Do and Bennett [12] to identify the biodiversity benefits of Tram Chim National Park. The study estimated 
the total benefits of wetland conservation program to be about $\$ 3.9$ million.

Due to this information gap among residents, farmers and policy makers, it is unclear to policymakers whether the change in current management practices would generate net social benefits. It is relatively easy to calculate the costs of biodiversity conservation program, but hard to estimate the benefits. The benefits or design of biodiversity policy could be estimated by studying public preferences on conservation program. However, this is complicated because of the generally low level of awareness and understanding of what biodiversity means on the part of the general public [9]. Moreover, although there are a lot of conservation activities especially in biosphere reserves of the Mekong Delta recognized by UNESCO, these are not strong or powerful enough to enlarge or improve the quantity and quality of biosphere reserves because of government budget constraint or the low level of support from local residents and authorities. Studies are needed to be done to answer the question of whether more financial investments are worthy for conserving biodiversity in these biosphere reserves. In this paper, using the approach of a choice modeling to estimate the economic values of the proposed biodiversity conservation program in U Minh Thuong National Park, one of the largest peat swamp forests in Vietnam, the study might partly seek to answer the question and also provide policy makers and concerned people more information about residents' attitudes toward environment and natural resources as well as the benefits of biodiversity conservation.

The paper is structured as follows. The next section describes the methodology and data collection including the parts of choice modeling technique; study area and conservation fund; survey and questionnaire design; and model specification. The following section reports the discussion results of a choice modeling analysis. The final section concludes the paper.

\section{Methods}

Choice modeling technique

Choice modeling (CM) technique has been recently paid much attention by economists. This approach was first developed by Louviere and Hensher [15] and then popularly applied in the fields of marketing, transportation and tourism [7, 21]. The CM method was originally developed from conjoint analysis, but differed from typical conjoint methods in terms of asking respondents to select one alternative from choice sets of attributes instead of ranking or rating them. Because of its consistency with random utility theory (RUT), CM has been used to estimate the passive use values of environmental goods [1].
Unlike the contingent valuation method that aims to value a specific trade-off, the CM technique needs respondents to select only one resource use option from each of some sets of multiple resource use options [5]. The method of CM identifies a function of the attributes and labels to predict respondents' choice behavior [23]. The choice experiment method is developed from Lancaster's theory of consumer choice based on the behavioral framework of RUT [17, 18]. RUT describes discrete choices in a maximum utility and its function $\left(U_{i j}\right)$ is assumed to form:

$U_{i j}=V_{i j}+e_{i j}=V\left(Z_{i j}, S_{i}\right)+e\left(Z_{i j}, S_{i}\right)$

where $V_{i j}$ is the systematic and deterministic component of the latent utility for conservation management scenario alternative $j$ in choice set $C ; e_{i j}$ is the random and error component [16]. The systematic component $V_{i j}$ could be specified as a function of the vectors of conservation management attributes $Z$ which illustrate the alternative $j$ and social, economic and attitudinal characteristics $S$ of the respondent $i$. Since the component is random, choices cannot be predicted certainly and perfectly. This leads to the expression of the probability of choice:

$P(i)=P\left(V_{i j}+e_{i j}>V_{i m}+e_{i m}\right) ; \forall m \in C$

Assuming that error terms are distributed independently and identically (IID) and follow Gumbell or Weibull distribution, the probability that alternative $h$ will be selected is estimated with multinomial logit model (MNL) [13, 18, 19] which is as follows:

$P(i)=\frac{\exp \left(V_{i j}\right)}{\sum_{j \in C} \exp \left(V_{i j}\right)}$

The utility function in linear parameters for the $j$ th alternative is specified as follows:

$\begin{aligned} V_{i j}= & \mathrm{ASC}+\beta_{1} Z_{1}+\beta_{2} Z_{2}+\beta_{3} Z_{3}+\cdots+\beta_{k} Z_{k} \\ & +\lambda_{1}\left(\mathrm{ASC} * S_{1}\right)+\cdots+\lambda_{p}\left(\mathrm{ASC} * S_{p}\right)\end{aligned}$

where $k$ is the number of attributes and $p$ the number of socioeconomic variables. The parameters of $\beta$ are often not specified and vary with the alternatives in the choice sets, meaning that the impact of a choice-specific variable on the odds of a given option being chosen is the same without the consideration of alternatives. ASC is defined as the alternative specific constants of the MNL model and unique for each of the alternatives considered in the choice sets. ASC captures the mean effect of unobserved factors in the error terms for each alternative. Although there are several possible ways to eliminate the violations of irrelevant 
alternatives (IIA) and improve model fit, this study analyzes the MNL model including socioeconomic attributes in the hope of reducing bias and obtaining more accuracy in the results of the choice model [23].

Study area and conservation fund

U Minh Thuong National Park is one of two large areas of peat swamp forest in Vietnam. Biodiversity conservation in this region has been assigned a national priority, since it could buffer the negative effects of the Mekong River floods, recharge aquifers and provide a unique environment for many wetland species. With a total area of 8.038 ha and a buffer zone of 13.069 ha, the park is a home to many diversified plants and animals including 243 plants, 32 mammals, 151 birds, 34 reptiles, 7 amphibians, 34 fish and 181 insect species. Forty of these are listed as endangered species in the Vietnam Red Book [11].

Although the government has declared it a protected zone, U Minh Thuong National Park is still under serious threats to biodiversity such as an increase in human encroachment on and disturbance of wildlife habitats by converting the forest land into agriculture and construction land, environmental pollution caused by subsistence wastes, industrial wastes, use of insecticides, herbicides and toxic rat baits, and illegal wildlife hunting and trade.

This study proposed a fund for a biodiversity conservation project to increase the number of plants and animals in U Minh Thuong or at least keep them from declining every year. The conservation fund could then request international organizations to provide the same amount of money or more compared with the contributions of citizens. The money raised by the fund would be only used for the following conservation activities: (1) rationally planning ponds, shrimp ponds and rice farming land around the buffer zone to prevent water pollution and scarcity of food; (2) planting more trees suitable for nesting and reproducing, improving ponds, swamps and grassland within and outside the buffer zone to create a food source and the better living environment for wild animals; and also planting trees in rural areas, industrial zones and urban areas to create good habitat conditions for biodiversity conservation; (3) enhancing the coverage of forest to protect the soil from erosion, landslides and runoff; (4) conducting education and training activities to improve the awareness of the local people to conserve biodiversity and the professional skills of the management group staff.

\section{Survey and questionnaire design}

The most important step in designing the choice experiment questionnaire is to identify good attributes and their levels to be valued. In this study, we proposed different
Table 1 Attributes and levels used in the choice experiment

\begin{tabular}{lrl}
\hline Attribute & Base level & Alternative levels \\
\hline Percentage of healthy vegetation & 60 & $70,80,90$ \\
Number of mammal species & 30 & $45,60,75$ \\
Number of bird species & 150 & $170,190,210$ \\
Number of reptile species & 45 & $65,85,105$ \\
Number of farmers worse off & 0 & $400,800,1,200$ \\
$\begin{array}{l}\text { Surcharge on household water } \\
\text { bills in thousand VND }\end{array}$ & 0 & $10,35,60,85,110$ \\
\hline
\end{tabular}

conservation management scenarios with their attributes determined in consultation with experts in the U Minh Thuong National Park and environmental economists at Can Tho University, and based on previous researches (e.g., Bennett et al. [2]; Do and Bennett [12] ). The focus group with the potential respondents and pilot survey of 50 respondents was then conducted to confirm the final attributes and levels necessary to the public and refine the questionnaire more clearly and concisely. The pilot survey also helped interviewers get used to the way to ask and understand the content of the questionnaire.

Table 1 shows the selected attributes and their level of choice experiment. The assumptions are that the conservation management strategies would create positive environmental impacts such as increasing the percentage of healthy vegetation, the number of mammal species, the number of bird species and the number of reptile species, while the conservation activities also negatively affect farm viability meaning that some farmers might decrease the crop products, lose their cultivated lands or possibly leave their farm. These impacts were used as attributes of choice experiment (See Table 1). The payment vehicle was used as voluntary continuous donation, contributed through a monthly water bill for 3 years, which could catch the present value of preferences for biodiversity conservation and also prevent potential protests due to compulsory payment like taxes [23]. The payment levels of VND $10,000,35,000,60,000,85,000$ and 110,000 selected for the study are based on the focus group and pilot survey. These values are equivalent to values in US dollars ${ }^{1}$ of $\$ 0.47, \$ 1.66, \$ 2.84, \$ 4.21$ and $\$ 5.20$, respectively.

The choice experiment data were collected by randomly interviewing local residents face to face in the urban area of Can Tho City, representing the biggest city in the Mekong Delta and the urban region of Kien Giang Province where U Minh Thuong National Park is located. Following Louviere et al. [16], experimental design technique or conjoint choice modeling technique in main effects was applied to generate 25 orthogonal combinations which were blocked into five

\footnotetext{
$11 \mathrm{USD}=21,140 \mathrm{VND}$ at the date of 05/12/2013.
} 
Table 2 Profile examples of choice set

\begin{tabular}{llll}
\hline $\begin{array}{l}\text { The following factors will vary } \\
\text { under different managements }\end{array}$ & $\begin{array}{l}\text { Alternative } \\
\text { A (Status quo) }\end{array}$ & Alternative B & Alternative C \\
\hline $\begin{array}{l}\text { Percentage of healthy } \\
\text { vegetation (\%) }\end{array}$ & 60 & 80 & 90 \\
$\begin{array}{l}\text { Number of mammal species } \\
\text { Number of bird species }\end{array}$ & 30 species & 45 species & 60 species \\
Number of reptile species & 45 species & 85 species & 170 species \\
$\begin{array}{l}\text { Number of farmers worse off } \\
\text { Surcharge on household }\end{array}$ & 0 & 800 & 105 species \\
water bills & No change & Increase by VND 85,000 & Increase by VND 110,000 \\
\hline
\end{tabular}

different questionnaire versions, each including five choice sets. The total collected samples are 366 respondents, with 215 in Can Tho and 151 in Kien Giang.

Before the choice modeling (CM) question was asked, the current conditions, biodiversity as well as the benefits of U Minh Thuong National Park were introduced with the suggestion of biodiversity loss threats. A hypothetical conservation program was proposed to prevent biodiversity losses in the national park. The current biodiversity will continue to degrade more seriously without this conservation project. In the CM question, each respondent was asked to answer five choice sets, choosing among three alternatives which show various options of biodiversity conservation management in U Minh Thuong National Park (see Table 2 for an example). Alternative A is a status quo scenario level with no negative effects of farmer and no extra charge in a monthly water bill. Alternatives B and $\mathrm{C}$ comprise farmer worse off and extra charge because of biodiversity conservation activities. To avoid presenting respondents an alternative with costs equal to the current situation, each alternative in choice sets has at least one level of biodiversity attributes higher than the status quo. Besides multiple choice questions, the questionnaire also includes respondents' socioeconomic information on age, gender, education and income, and their knowledge as well as attitudes toward the issues of the environment and biodiversity. This is very essential to reduce potential information bias because of the limitation of respondents' knowledge in terms of biodiversity conservation [14].

\section{Model specification}

We applied an MNL model to identify the relationships of choice experiment data. The model parameters were estimated by the software NLOGIT 4.0. Following suggestions by Bennett et al. [2], to illustrate the diminishing marginal values for increases in attributes levels, the variables of Vegetation, Mammal, Bird and Reptile are structured in $1 / x$ form. Since the attributes of Farmer loss and Cost are zero at the status quo level, they are considered to be linear. The model was specified as follows:
Status quo : $V_{1}=\beta_{1} \operatorname{Cost}+\beta_{2} * 1 /$ Vegatation

$$
\begin{aligned}
& +\beta_{3} * 1 / \text { Mammal }+\beta_{4} * 1 / \text { Bird } \\
& +\beta_{5} * 1 / \text { Reptile }+\beta_{6} * \text { Farmer loss }
\end{aligned}
$$

Alternative 1: $V_{2}=\mathrm{ASC}+\beta_{1} \operatorname{Cost}+\beta_{2} * 1 /$ Vegatation

$$
\begin{aligned}
& +\beta_{3} * 1 / \text { Mammal }+\beta_{4} * 1 / \text { Bird } \\
& +\beta_{5} * 1 / \text { Reptile }+\beta_{6} * \text { Farmer loss } \\
& +\sum_{k=1}^{p} \lambda_{k}\left(\text { ASC } * S_{k}\right)
\end{aligned}
$$

Alternative $2: V_{3}=\mathrm{ASC}+\beta_{1} \operatorname{Cost}+\beta_{2} * 1 /$ Vegatation

$$
\begin{aligned}
& +\beta_{3} * 1 / \text { Mammal }+\beta_{4} * 1 / \text { Bird } \\
& +\beta_{5} * 1 / \text { Reptile }+\beta_{6} * \text { Farmer loss } \\
& +\sum_{k=1}^{p} \lambda_{k}\left(\mathrm{ASC} * S_{k}\right)
\end{aligned}
$$

where $V_{j}$ is the utility function associated with alternative $j$. $S_{k}$ are socioeconomic and attitudinal variables which are added to the equation by interacting them with ASC for each equation. The choice experiment model is estimated with the hypothesis of the observable utility function in the additive form.

\section{Results and discussion}

The data from the choice experiment method are estimated using an MNL model [16]. The variables and their coding for the model are presented in Table 3. The socioeconomic characteristics of respondents, their knowledge and attitudes toward biodiversity issues including the model are also shown in Table 4.

Table 4 shows the socio-demographic description of the respondents. The age of surveyed respondents ranges from 20 to 87 years with the average age of 50 years and about $61 \%$ of respondents are female. The high percentage of 
Table 3 Variables used in the choice model

\begin{tabular}{|c|c|}
\hline Variable & Description \\
\hline \multicolumn{2}{|c|}{ Attribute variable } \\
\hline Cost & $\begin{array}{l}\text { Surcharge on the monthly water bills (thousand } \\
\text { VND) }\end{array}$ \\
\hline Vegetation & Percentage of healthy vegetation \\
\hline Mammal & Number of mammal species \\
\hline Bird & Number of bird species \\
\hline Reptile & Number of reptile species \\
\hline Farmer loss & $\begin{array}{l}\text { Number of farmers who may leave as a result of } \\
\text { management changes }\end{array}$ \\
\hline \multicolumn{2}{|c|}{ Non-attribute variable } \\
\hline Age & Age of respondents (years) \\
\hline Gender & $\begin{array}{l}\text { Dummy variable equaling } 1 \text { for male and } 0 \text { for } \\
\text { female respondents }\end{array}$ \\
\hline Education & Education of respondents (years) \\
\hline Income & Monthly income of respondents (thousand VND) \\
\hline Knowledge & $\begin{array}{l}\text { Five-point scale indicating the biodiversity } \\
\text { knowledge of respondents }\end{array}$ \\
\hline Enviconcern & $\begin{array}{l}\text { Dummy variable equaling } 1 \text { for respondents who } \\
\text { have contributed environmental funds and } 0 \\
\text { otherwise }\end{array}$ \\
\hline Location & $\begin{array}{l}\text { Dummy variable equaling } 1 \text { for Can Tho and } 0 \text { for } \\
\text { Kien Giang }\end{array}$ \\
\hline
\end{tabular}

Knowledge: respondents who were asked five questions related to biodiversity knowledge and received one point for answering each question correctly

Table 4 Socio-demographics of respondents

\begin{tabular}{llllrr}
\hline Attribute & Unit & Mean & SD & Min & Max \\
\hline Age & Year & 49.71 & 14.28 & 20 & 87 \\
Gender & - & 0.39 & 0.49 & 0 & 1 \\
Education & Year & 11.66 & 3.18 & 5 & 18 \\
Income & Thousand VND & 7,546 & 4,07 & 4,500 & 19,500 \\
Knowledge & Point & 3.27 & 1.34 & 0 & 5 \\
Enviconcern & - & 0.24 & 0.43 & 0 & 1 \\
Location & - & 0.59 & 0.49 & 0 & 1 \\
\hline
\end{tabular}

Source: own estimates; data appendix available from authors

female respondents may be due to the survey mainly done in the daylight of weekdays, because it is difficult to interview working male households at that time. On average, respondents who stated attending school for nearly 12 years had a household income of VND 7.5 million per month, with the most frequent category of below VND 5 million $(40 \%)$, followed by VND 5 million-10 million (about $39 \%$ ), and over VND 10 million (nearly $21 \%$ ).

Table 5 shows the MNL model results of choice experiment data. Model 1 is the estimated result of model with attribute variables only, while Model 2 includes attribute variables and interaction variables that are generated by interacting non-attribute variables (e.g., socioeconomic characteristics, knowledge and attitudes) with the alternative specific constant (ASC). According to Rolfe et al. [23], the choice model including socioeconomic variables could improve model fit and remove the IIA and IID violations. The study shows that Model 2 has a higher level of parametric fit than Model 1 because of the bigger values of $\log$ likelihood and $\rho^{2}$ in Model 2 compared with those of Model 1. These improvements could be tested for significance by applying Swait-Louviere log-likehood ratio test. The likehood ratio test statistic ${ }^{2}$ is LR $=2(1,667.901-$ $1,617.122)=101.558$ which exceeds the critical value of the Chi-square distribution of 14.067 at the $95 \%$ significance level on 7 degrees of freedom. ${ }^{3}$ The result indicates that Model 2 has model fit improvements and better results compared with Model 1. Thus, Model 2 will be used for the final results for interpretations of choice experiment model.

All the coefficients of Model 2, excepting the attributes of Bird and Reptile, are significantly different from zero and have signs as expected at the $5 \%$ significance level. The insignificant parameters of $1 /$ Birds and 1/Reptile variables indicate that an increase in the species of birds and reptiles is not a major concern for the surveyed residents. Since the variables of Vegetation and Mammal are structured in $1 / x$ form, their significantly negative coefficients reveal that respondents select their choice options with concern of an increase in the area of vegetation and the number of mammal species. In addition, the negative significance of Farmer loss attribute indicates respondents also pay much attention to the welfare losses of local farmers.

Moreover, similar to the result of other studies written by Carlsson et al. [6], Othman et al. [22] and Wang et al. [25], Model 2 shows that older respondents are more likely to select the status quo alternative than younger since the interaction variable of ASC*Age has a significantly negative parameter at the level of $5 \%$. The coefficients of variables Education and Income interacting with ASC are significantly positive at the $1 \%$ level, showing that respondents with higher education are more likely to support the biodiversity conservation project, and those with higher income are willing to pay more, which are consistent with the previous studies (e.g., Morrison et al. [20], Carlsson et al. [6], Othman et al. [12], Birol et al. [3], Do and Bennett [12]). Regarding the biodiversity knowledge and conservation motivations, The variable of Knowledge is defined as total points of respondents obtained for correctly answering five questions related to biodiversity, while that of Enviconcern is a dummy variable equaling 1

\footnotetext{
$\overline{2}$ Calculated by the formula $\mathrm{LR}=-2\left(\mathrm{LL}_{1}-\mathrm{LL}_{2}\right)$, where $\mathrm{LL}_{x}$ is the log-likelihood statistics for the different models.

3 The degrees of freedom are given by the difference in the numbers of parameters estimated in the two models.
} 
Table 5 Estimated results of multinomial logit model for biodiversity conservation
$* * *, * *, *$ Indicate statistical significance at the $0.01,0.05$ and 0.1 level, respectively

Source: own estimates; data appendix available from authors

\begin{tabular}{|c|c|c|c|c|}
\hline \multirow[t]{2}{*}{ Variables } & \multicolumn{2}{|l|}{ Model 1} & \multicolumn{2}{|l|}{ Model 2} \\
\hline & Coefficient & Standard error & Coefficient & Standard error \\
\hline ASC & -0.1133 & 0.3226 & $-5.9553 * * *$ & 1.0887 \\
\hline Cost & $-0.0202 * * *$ & 0.0013 & $-0.0206^{* * *}$ & 0.0013 \\
\hline 1/Vegetation & $-102.6570 * * *$ & 32.5996 & $-101.1519 * * *$ & 32.8916 \\
\hline 1/Mammal & $-17.4669 * *$ & 8.8614 & $-17.8351^{* *}$ & 8.9360 \\
\hline 1/Bird & -44.9151 & 92.4329 & -51.5904 & 93.5985 \\
\hline 1/Reptile & -0.2403 & 17.5903 & -1.6043 & 17.7985 \\
\hline Farmers loss & $-0.0005 * * *$ & 0.0001 & $-0.0005 * * *$ & 0.0001 \\
\hline ASC*Age & & & $-0.0079 * *$ & 0.0037 \\
\hline ASC*Gender & & & $-0.4035^{* * *}$ & 0.1065 \\
\hline ASC*Education & & & $0.0664 * * *$ & 0.0186 \\
\hline ASC*Income & & & $0.5852 * * *$ & 0.1252 \\
\hline ASC*Knowledge & & & $0.1539 * * *$ & 0.0460 \\
\hline ASC*Enviconcern & & & $0.2714 * *$ & 0.1187 \\
\hline ASC*Location & & & $-0.2292 * *$ & 0.1075 \\
\hline Log-likelihood & $-1,667.901$ & & $-1,617.122$ & \\
\hline$\rho^{2}$ & 0.0746 & & 0.10272 & \\
\hline Observation & 1,800 & & 1,800 & \\
\hline
\end{tabular}

if a respondent has ever donated for any environmental funds and 0 otherwise. The coefficients of ASC* Enviconcern and ASC*Knowledge are significantly positive, similar to other findings of Blamey et al. [4], Colombo et al. [10], and Do and Bennett [12]. Respondents who have high biodiversity knowledge or made any environmental contributions are more willing to pay for the biodiversity conservation project.

The marginal willingness to pay (MWTP) measure the amount of money respondents are willing to pay to trade off for a unit improvement in an environmental attribute or the amount they are willing to pay to prevent the welfare losses of farmer. The equation for calculating MWTP for the environmental attributes is given by:

MWTP $=-\frac{-1}{\text { attribute level }^{2}} * \frac{\beta_{\text {non-monetary attribute }}}{\beta_{\text {monetary attribute }}}$

The MWTP formula for the welfare losses of farmers is as follows:

$\mathrm{MWTP}=-\frac{\beta_{\text {non }- \text { monetary attribute }}}{\beta_{\text {monetary attribute }}}$

The MWTPs of Vegetation, Mammal, Bird and Reptile attributes are different depending on the level of attributes due to their functional form, while that for Farmer loss is a constant. From the findings in Table 5 and applying the estimator (8) and (9), the MWTP for each of conservation management attributes at the midpoint levels used in the survey are calculated by utilizing Wald procedure (Delta method). The results of MWTP values are presented in Table 6.

Table 6 shows the results of MWTP estimates for each of biodiversity attribute. Residents in the sample agree to pay on average VND 913 monthly for an additional percent of healthy vegetation with the $95 \%$ confidence interval between VND 324 and VND 1502. They are willing to pay VND 360 for increasing one more mammal species in $U$ Minh Thuong National Park, while they agree to contribute about VND 2,440 per household to avoid the welfare losses of 100 farmers with the $95 \%$ confidence interval between VND 1,150 and VND 3,740.

Moreover, based on the findings in Table 6, the study also estimates marginal rates of substitution between nonmonetary attributes presented as follows:

1. $1 \%$ extra healthy vegetation $=2.6$ extra numbers of mammal species $=39.6$ more farmers worse off

2. An additional number of mammal species $=0.39 \%$ extra healthy vegetation $=14.8$ more farmers worse off

3. 100 more farmers worse off $=2.67 \%$ extra healthy vegetation $=6.8$ extra numbers of mammal species

The benefits for an additional percent of healthy vegetation are valued equal to approximately 2.6 extra numbers of mammal species and the welfare losses of 39.6 local farmers. Respondents are willing to trade off between 100 farmers worse off due to biodiversity conservation activities and $2.67 \%$ extra healthy vegetation or an increase in 6.8 numbers of mammal species. 
Table 6 MWTP estimates and confidence intervals $(95 \%$ level)

\section{Unit: 1,000 VND}

Source: own estimates; data appendix available from authors $C I$ confidence interval, $L B$ lower bound, $U B$ upper bound, $n s$. not significant

\begin{tabular}{|c|c|c|c|c|c|c|}
\hline \multirow[t]{3}{*}{ Variables } & \multicolumn{3}{|l|}{ Model 1} & \multicolumn{3}{|l|}{ Model 2} \\
\hline & \multirow[t]{2}{*}{ MWTP } & \multicolumn{2}{|l|}{$95 \% \mathrm{CI}$} & \multirow[t]{2}{*}{ MWTP } & \multicolumn{2}{|l|}{$95 \% \mathrm{CI}$} \\
\hline & & LB & UB & & LB & UB \\
\hline Vegetation & $0.9472 * * *$ & 0.3496 & 1.5448 & $0.9129 * * *$ & 0.3235 & 1.5022 \\
\hline Mammal & $0.3606 * *$ & -0.0002 & 0.7214 & $0.3601 * *$ & 0.0041 & 0.7161 \\
\hline Bird & ns. & & & ns. & & \\
\hline Reptile & ns. & & & ns. & & \\
\hline Farmer loss & $-0.0239 * * *$ & -0.0370 & -0.0107 & $-0.0244 * * *$ & -0.0374 & -0.0115 \\
\hline
\end{tabular}

\section{Conclusions}

This study reported results from the application of choice experiment to assess Vietnamese households' preferences and motivations for biodiversity conservation in the Mekong Delta of Vietnam. The results showed that a significant portion of residents were willing to pay for management activities to preserve biodiversity. However, a majority of respondents chose the status quo alternative because they simply did not care or had other priorities than biodiversity conservation. Only $34 \%$ of respondents were willing to pay for the proposed conservation project (respondents who selected an alternative to status quo at least one were considered to be willing to pay). The reasons for their willingness to pay were an increase in healthy vegetation and mammal species and prevention of the welfare losses of local farmers. Respondents were willing to trade off VND 913 monthly increase of household water bill for an additional percent of healthy vegetation, VND 360 for increasing one more mammal species and VND 2,440 for preventing the welfare losses of 100 local farmers. On the other hand, the insignificant attributes of Bird and Reptile revealed that respondents were not so much interested in an increase in bird and reptile species.

In addition, the results of interaction variables with the constant showed that older respondents were more likely to choose the status quo rather than the conservation project, while those with higher education, income, biodiversity knowledge or environmental concern revealed a higher likelihood of selecting the project. The findings from the estimates of marginal rates of substitution between nonmonetary attributes investigated that in the trade-off between biodiversity conservation and the welfare losses, for instance, to increase $1 \%$ extra healthy vegetation that was equivalent to nearly 3 extra numbers of mammal species, about 40 local farmers could be hurt in terms of the losses of cultivated land or productivity due to the activities of the conservation project. These values could be useful and trustworthy information for policy makers to make right decisions in terms of the cost-benefit analysis and the trade-off between biodiversity and economics, etc. in the biodiversity conservation project In addition, the public evaluation of biodiversity conservation could help produce more awareness in the society on the important role of biodiversity, have an impact on rational behaviors or wide support of residents and to improve the quantity or quality of biodiversity which benefits the present and future generation [8].

Acknowledgments We would like to express our gratitude to the Japan Society for the Promotion of Science (JSPS) for sponsoring the study. Our warmest thanks go to Dr. Hisako Nomura, Kyushu University for her invaluable comments, which led to significant improvement of the manuscript, and the staff in the department of Agricultural Economics and Resource-Environmental Economics, SEBA, Can Tho University for assisting in data collection.

Conflict of interest The authors declare that they have no competing interests.

Authors' contribution HVK designed the study questionnaire, collected and analyzed the data, and drafted the manuscript. MY supervised the research and made critical revisions to the manuscript. All authors read and approved the final manuscript.

Open Access This article is distributed under the terms of the Creative Commons Attribution License which permits any use, distribution, and reproduction in any medium, provided the original author(s) and the source are credited.

\section{References}

1. Adamowicz, W., Boxall, P., Williams, M., Louviere, J.: Stated preference approaches for measuring passive use values: choice experiments and contingent valuation. Am. J. Agric. Econ. 80(1), 64-75 (1998). doi: $10.2307 / 3180269$

2. Bennett, J., Bueren, M.V., Whitten, S.: Estimating Society's Willingness to Pay to Maintain Viable Rural Communities. In: The 46th Conference of the Australian Agricultural and Resource Economics Society, Canberra, Australia 2002

3. Birol, E., Karousakis, K., Koundouri, P.: Using a choice experiment to account for preference heterogeneity in wetland attributes: the case of Cheimaditida wetland in Greece. Ecol. Econ. 60(1), 145-156 (2006). doi:10.1016/j.ecolecon.2006.06.002

4. Blamey, R.K., Bennett, J.W., Louviere, J.J., Morrison, M.D., Rolfe, J.: A test of policy labels in environmental choice modelling studies. Ecol. Econ. 32(2), 269-286 (2000). doi:10.1016/ S0921-8009(99)00101-9

5. Boxall, P.C., Adamowicz, W.L., Swait, J., Williams, M., Louviere, J.: A comparison of stated preference methods for 
environmental valuation. Ecol. Econ. 18(3), 243-253 (1996). doi:10.1016/0921-8009(96)00039-0

6. Carlsson, F., Frykblom, P., Liljenstolpe, C.: Valuing wetland attributes: an application of choice experiments. Ecol. Econ. 47(1), 95-103 (2003). doi:10.1016/j.ecolecon.2002.09.003

7. Carson, R.T., Wright, J., Carson, N., Alberini, A., Flores, N.: A Bibliography of Contingent Valuation Studies and Papers. Natural Resource Damage Assessment, La Jolla (1995)

8. Chen, W., Jim, C.Y.: Resident motivations and willingness-topay for urban biodiversity conservation in Guangzhou (China). Environ. Manage. 45(5), 1052-1064 (2010). doi:10.1007/s00267010-9478-2

9. Christie, M., Hanley, N., Warren, J., Murphy, K., Wright, R., Hyde, T.: Valuing the diversity of biodiversity. Ecol. Econ. 58(2), 304-317 (2006). doi:10.1016/j.ecolecon.2005.07.034

10. Colombo, S., Hanley, N., Calatrava-Requena, J.: Designing policy for reducing the off-farm effects of soil erosion using choice experiments. J. Agric. Econ. 56(1), 81-95 (2005). doi:10.1111/j. 1477-9552.2005.tb00123.x

11. Dang, N.X.: Biodiversity survey—rapid assessment of flora and terrestrial animals in the key areas of Kien Giang Biosphere Reserve. In: Technical Report 09E0809DANG. Conservation and Development of the Biosphere Reserve of Kien Giang Province Project (2009)

12. Do, T.N., Bennett, J.: Estimating wetland biodiversity values: a choice modelling application in Vietnam's Mekong River Delta. Environ. Dev. Econ. 14(02), 163-186 (2009). doi:10.1017/ S1355770X08004841

13. Greene, W.H.: Econometric Analysis. Prentice Hall (2001)

14. Liljenstolpe, C.: Evaluating animal welfare with choice experiments: an application to Swedish pig production. Agribusiness 24(1), 67-84 (2008). doi:10.1002/Agr.20147

15. Louviere, J.J., Hensher, D.A.: Design and analysis of simulated choice or allocation experiments in travel choice modeling. Transp. Res. Rec. 890, 7 (1982)
16. Louviere, J.J., Hensher, D.A., Swait, J.D.: Stated Choice Methods: Analysis and Application. Cambridge University Press, Cambridge (2000)

17. Luce, R.D.: Decision-making—an experimental approachDavidson, D, Suppes, P. J. Philos. 56(4), 173-177 (1959). doi:10. 2307/2022058

18. Maddala, G.S.: Limited-Dependent and Qualitative Variables in Econometrics. Cambridge University Press, Cambridge (1986)

19. McFadden, D.: Conditional logit analysis of qualitative choice behavior. In: Zarembka, P. (ed.) Frontiers in Econometrics. Academic Press, New York (1974)

20. Morrison, M., Bennett, J., Blamey, R.: Valuing improved wetland quality using choice modeling. Water Resour. Res. 35(9), 2805-2814 (1999). doi:10.1029/1999wr900020

21. Morrison, M.D., Blamey, R.K., Bennett, J.W., Louviere, J.J.: A comparison of stated preference techniques for estimating environmental values. In: Choice Modelling Research Report No. 1. University College. University of New South Wales, Canberra (1996)

22. Othman, J., Bennett, J., Blamey, R.: Environmental values and resource management options: a choice modelling experience in Malaysia. Environ. Dev. Econ. 9, 803-824 (2004). doi:10.1017/ s1355770X04001718

23. Rolfe, J., Bennett, J., Louviere, J.: Choice modelling and its potential application to tropical rainforest preservation. Ecol. Econ. 35(2), 289-302 (2000). doi:10.1016/S0921-8009(00) 00201-9

24. Thuy, D.T.: Willingness to Pay for Conservation of the Vietnamese Rhino. In. The Economy and Environment Program for Southeast Asia (EEPSEA) (2007)

25. Wang, X.H., Bennett, J., Xie, C., Zhang, Z.T., Liang, D.: Estimating non-market environmental benefits of the Conversion of Cropland to Forest and Grassland Program: a choice modeling approach. Ecol. Econ. 63(1), 114-125 (2007). doi:10.1016/j.eco lecon.2006.10.001 